\title{
PERUBAHAN PSIKOLOGIS PADA IBU HAMIL TRIMESTER III
}

\section{ADAPTATION OF PSYCHOLOGICAL CHANGES IN THE THIRD SEMESTER OF PREGNANT WOMEN}

\author{
R. Nety Rustikayanti ${ }^{1^{\star}}$, Ira Kartika ${ }^{2}$, Yanti Herawati ${ }^{3}$ \\ ${ }^{1,2,3}$ STIKes Dharma Husada Bandung, Jln. Terusan Jakarta no.75, Bandung 40291, Indonesia
}

Informasi Artikel:

Diterima: April 2016

Disetujui: Oktober 2016

Kata kunci:

Perubahan psikologis

ibu hamil

Tingkat kepuasan suami

Kata kunci 1

Perubahan psikologis

ibu hamil

Kata kunci 2

Tingkat kepuasan suami

\begin{abstract}
ABSTRAK
Seorang wanita pada periode kehamilan akan mengalami perubahan baik fisik maupun psikologis. Perubahan ini berdampak terhadap pemenuhan kebutuhan dasar termasuk seksualitas. Penelitian ini bertujuan untuk menggambarkan perubahan psikologis ibu hamil. Penelitian menggunakan rancangan cross sectional dengan populasi ibu hamil trimester 3 yang memeriksakan kehamilannya di bulan Mei 2015 sebanyak 183 pasangan. Teknik sampling menggunakan accidental sampling dan jumlah sampel terpilih adalah 46 pasangan. Instrumen yang digunakan berupa kuesioner Perubahan Psikologis dan Index of Sexual Satisfaction (ISS). Analisis data menggunakan Chi-square test. Hasil penelitian menunjukkan bahwa sebanyak $54.3 \%$ responden mengalami perubahan psikologis positif
\end{abstract}

\begin{abstract}
A woman on the gestation period will experience both physical and psychological changes. These changes have an impact on the fulfillment of basic needs, including sexuality. Changes in pregnant women's perceived psychology can result in decreased sexual desire of the women. This study aimed to describe the relationship of psychological changes of pregnant women with the husband's sexual satisfaction level. The study used cross sectional design with a population of third trimester pregnant women who did checkups in May 2015 as many as 183 couples. Sampling technique used accidental sampling and sample size was 46 couples. The instrument used was a questionnaire and Psychological Changes Index of Sexual Satisfaction (ISS). Data analysis used Chi-square test. The results showed that as many as $54.3 \%$ of respondents experienced a positive psychological change. Conclusion of the study is that the more positive physiological changes in pregnant women will result in higher sexual satisfaction of her husband.
\end{abstract}

\section{PENDAHULUAN}

Kehamilan merupakan suatu peristiwa penting dalam kehidupan seorang perempuan. Proses yang diawali dari konsepsi hingga pengeluaran bayi dari dalam rahim menuntut adaptasi dari ibu hamil dan orang-orang terdekat. Kehamilan bagi pasangan suami istri adalah suatu perkembangan keluarga dengan hadirnya anggota keluarga baru, perubahan hubungan, dan peran dalam keluarga (Hapsari \& Sudarmiati, 2011).

Ibu hamil akan mengalami perubahan fisik seperti keluhan mual, muntah, pusing, dan mudah lelah. Indra penciuman juga menjadi sangat peka, dan oleh karena itu, tak jarang kita melihat ibu hamil muda yang tampak begitu tegang dan mudah emosi. Hal itu biasanya kita temui di trimester pertama. Pada masa kehamilan trimester kedua, ibu hamil merasakan perubahan bentuk tubuhnya, terutama pada wajah, perut, dan dada. Dalam fasie ini, beberapa ibu hamil merasa cemas karena takut akan bertambahnya berat badan. Di trimester ketiga, ibu hamil sering mengeluhkan mudah lelah dan kurang tidur (Tari \& Romania, 2011).

Kehamilan mengakibatkan banyak perubahan dan adaptasi pada ibu hamil dan pasangan. Trimester pertama sering dianggap sebagai periode 
penyesuaian dengan ambivalensi (dua perasaan yang bertentangan) yang terkadang timbul. Beberapa ketidaknyamaan akan timbul pada ibu hamil, yang salah satunya berhubungan dengan ketidaknyamanan fisik dan perasaan. Berhubungan dengan hasrat seksual, setiap wanita memiliki hasrat seksual yang berbeda-beda di trimester pertama, karena banyak ibu hamil merasakan kebutuhan kasih sayang besar dan cinta tanpa seks.

Trimester kedua sering dikenal dengan periode kesehatan yang baik, yakni ketika ibu hamil merasa nyaman dan bebas dari segala ketidaknyamanan. Di trimester kedua ini, sebagian ibu hamil akan mengalami kemajuan dalam hubungan seksual. Hal itu disebabkan di trimester kedua, ibu hamil relatif terbebas dari segala ketidaknyamanan fisik, kecemasan, kekhawatiran yang sebelumnya menimbulkan ambivalensi pada ibu hamil kini mulai mereda dan menuntut kasih sayang dari pasangan maupun dari keluarganya (Ramadani \& Sudarmiati, 2013).

Kehamilan pada trimester ketiga sering disebut sebagai fase penantian yang penuh dengan kewaspadaan. Pada periode ini, ibu hamil mulai menyadari kehadiran bayi sebagai makhluk yang terpisah sehingga dia menjadi tidak sabar dengan kehadiran bayinya tersebut. Ibu hamil merasakan kembali ketidaknyamanan fisik karena merasa canggung atau merasa dirinya tidak menarik lagi, sehingga dukungan dari pasangan sangat dia butuhkan. Peningkatan hasrat seksual yang pada trimester kedua menjadi menurun karena abdomen yang semakin membesar yang rmenjadi halangan dalam berhubungan seks (Ramadani \& Sudarmiati, 2013).

\section{METODE PENELITIAN}

Penelitian ini menggunakan rancangan penelitian cross sectional. Populasi dalam penelitian ini adalah ibu hamil trimester 3 yang memeriksakan kehamilannya di bulan Mei tahun 2015 di UPT Puskesmas Arcamanik kota Bandung sebanyak 183 orang. Sampel penelitian diambil dengan metode accidental sampling. Pengumpulan data dilakukan dengan wawancara berdasarkan kuesioner tentang tingkat kepuasan seksual dan kuesioner perubahan psikologis ibu hamil. Kuesioner tingkat kepuasan seksual bersifat pertanyaan tertutup dan diukur dengan mengugunakan alat ukur ISS (index of sexual satisfaction) berdasarkan internatonal journal of psychology and psychology therapy (ISS). Untuk mengetahui kondisi psikologis ibu hamil, peneliti menggunakan kuesioner perubahan psikologis ibu hamil dengan kuesioner yang sudah diuji validitas dan reliabilitasnya. Metode analisis data yang digunakan adalah chi square test.

\section{HASIL DAN PEMBAHASAN}

Kehamilan mengakibatkan banyaknya perubahan pada ibu hamil, baik perubahan secara fisik dan psikologis. Hal itu di dipengaruhi juga oleh perubahan hormon pada ibu hamil, sehingga muncul keinginan untuk banyak istirahat dan perasaan yang ambivalensi. Perubahan bentuk tubuh juga dapat mempengaruhi respon emosional pada ibu hamil, seperti perubahan bentuk citra tubuh, dan perasaan takut dan cemas terhadap kehamilan.

Tabel 1. Distribusi Frekuensi Perubahan Psikologis Ibu Hamil Trimester 3

\begin{tabular}{lcc}
\hline $\begin{array}{c}\text { Perubahan psikologis } \\
\text { ibu hamil }\end{array}$ & $\begin{array}{c}\text { Jumlah } \\
(\mathbf{n})\end{array}$ & $\begin{array}{c}\text { Persentase } \\
(\boldsymbol{\%})\end{array}$ \\
\hline Perubahan psikologis positif & 25 & 54,3 \\
Perubahan psikologis negatif & 21 & 45,7 \\
\hline Total & $\mathbf{4 6}$ & $\mathbf{1 0 0}$ \\
\hline
\end{tabular}

Berdasarkan tabel 1 dapat dilihat bahwa perubahan psikologis ibu hamil trimester 3 yang terbanyak adalah mengalami perubahan psikologis positif sebanyak 25 orang $(54,3 \%)$.

Dalam penelitian ini, ibu hamil mengalami perubahan psikologis seperti merasa khawatir dengan perubahan bentuk tubuh yang dialami di masa kehamilan. Kekhwatiran juga muncul dikarenakan terhadap janin yang bisa saja lahir dengan kondisi tidak normal. Biasanya, 
perubahan-perubahan psikologis negatif dialami oleh ibu hamil dengan kehamilan pertama kali.

Di awal kehamilan, ibu hamil selalu memperhatikan setiap perubahan-perubahan yang dialaminya, baik perubahan fisik maupun psikologis. Terjadinya perubahan fisik seperti mual, muntah, perut yang semakin membesar, cepat lelah dan nyeri payudara dapat mempengaruhi psikologis ibu pada saat hamil, namun ada beberapa ibu hamil tidak mengalami perubahan psikologis yang tampak atau mengalami perubahan psikologis yang positif. Hal ini senada dengan hasil penelitian lain bahwa perubahan psikologis yang positif akan sering dialami ibu hamil yang telah memiliki pengalaman dengan kehamilan sebelumnya, sementara perubahan yang negatif sering muncul pada ibu hamil yang belum punya pengalaman hamil sebelumnya atau hamil pertama kali (Sandy \& Sari, 2012).

Kehamilan merupakan kondisi yang penuh dengan stres yang berdampak terhadap status psikis pada perempuan hamil (Bjelica A dan Kapor-Stanulović N, 2004). Fokus utama perempuan hamil adalah persepsi terhadap hilangnya daya tarik mereka. Persepsi ini berkorelasi terhadap aktivitas koitus dan kesenangan seksual terhadap pasangan (Perkins dalam Brown, C dan Bradford, J, 2008). Penelitian Judicibous dan McCabe (2002) menunjukkan adanya penurunan seksualitas selama kehamilan.

Kehamilan merupakan satu langkah dalam perkembangan hubungan seksualitas antara dua individu. Pasangan mungkin menghadapi masalahmasalah seksualitas selama kehamilan. Ketertarikan dalam aktifitas seksual umumnya ditolak selama kehamilan (Brown, C, Bradford, J, et al, 2008). Hubungan seksual bukanlah hanya bertemunya secara keadaan fisik antara seorang pria dan wanita, tetapi bertemunya keadaan psikologis dari kedua individu tersebut. Semua curahan hatinya, curahan perasaannya dinyatakan pada waktu berhubungan seksual.

Bicara soal gairah seks dan kehamilan, ternyata bukan hanya wanita saja yang merasakan penurunan libido, pria juga ternyata bisa mengalami hal serupa. Hal itu disebabkan karena kehamilan merupakan hal yang sudah jelas untuk wanita, kita terkadang melupakan bahwa bagaimana pengalaman ini juga mempengaruhi pasangan suami.

Selama kehamilan, istri mengalami perubahan dan adaptasi baik secara fisik maupun psikologis. Beberapa perubahan psikologis tersebut dapat berpengaruh terhadap aktivitas seksual pasangan dan mempengaruhi psikologis pasangan untuk melakukan aktifitas seksual dimasa kehamilan. Kekhawatiran membahayakan janin, keguguran, dan penurunan gairah seksual dapat membuat pasangan suami istri untuk tidak berhubungan seksual di masa kehamilan.

Perubahan dorongan seksual umumnya berfluktuasi selama masa kehamilan. Dorongan seksual biasanya menurun pada trimester dan meningkat di trimester dua, tetapi di sepanjang trimester ketiga dorongan seksual dapat kembali menurun dengan semakin membesarnya perut dan semakin fokusnya perhatian untuk persiapan melahirkan (Salma, 2012).

Perubahan hasrat atau keinginan istri yang berubah-ubah pada tiap trimester ternyata tidak sebanding dengan hasrat atau keinginan suami pada saat istri hamil. Di dalam sebuah jurnal ( Hapsari, 2015), hasrat atau gairah ibu hamil dalam melakukan seksual selama masa kehamilan berbeda dengan apa yang dirasakan suami. Hal ini tentunya berpengaruh terhadap psikologis ibu hamil dan tingkat kepuasan seksual suami pada masa kehamilan istri.

\section{KESIMPULAN}

Terdapat perubahan psikologis ibu hamil yang dapat berdampak pada gairah seksual sang istri. Oleh karena itu, pemberian penyuluhan serta informasi tentang perubahan fisik dan psikologis dalam masa kehamilan yang mungkin berpengaruh terhadap hubungan seksual suami dan ibu hamil perlu diberikan. 


\section{DAFTAR PUSTAKA}

Alek A . (2010). Cara Menikmati Masa Kehamilan.

http://www.tribunpontianak.co.id/read/artikel. Di akses pada tanggal 23/03/2015.

Allen J, (2014). Timing of sexual intercourse in relation to ovulation. http://www.nejm.org/doi/full/10.1056/NEJM199 512073332301. Di akses pada tanggal 27/02/2015.

Arikunto, S. 2010. Prosedur Penelitian Suatu Pendekatan Praktek. Jakarta, PT.Rineka Cipta.

Bjelica, A. Kapor-Stanulović N. 2004. Pregnancy as Psychological Event. Med Pregl. http://www.ncbi.nlm.nih.gov/pubmed/154 62597. pada tanggal 20/10/2015.

BKKBN, 2006. Deteksi dini komplikasi kehamilan. Jakarta.

Brown, C, Bradford, J et al. 2008. Sex and Sexuality in Pregnancy. The Global Library of Women's,Medicine. http://www.glowm.com/section_view/head.i ng/Sex\%20and\%20Sexuality\%20in\%20Pre gnancy/item/111. Pada tanggal 20/10/2015.

Chandranita, Fajar \& Bagus Gde. 2009. Repoduksi wanita. Jakarta : EGC

Christine Dunkel Schetter dan Lynlee.2015. Anxiety, depression and stress in pregnancy: implications for mothers, children, research, and practice.

http://www.ncbi.nlm.nih.gov/pmc/articles/P MC4447112/. Di akses pada tanggal 03/06/2015.

De Judicibus, M.A., McCabe, M.P. 2002. Psychological Factors and The Sexuality of Pregnant and Postpartum Women. The Journal of Sex Research. http://www.jstor.org/stable/3813191?seq=1\# page_scan_tab_contents. Pada 20/10/2015

Giovani Cedli. L . 2012. Fungsi Seksual Pasangan Selama Kehamilan. Skripsi ini tidak diterbitkan. Universitas Indonesia. Online. Di akses pada tanggal 05/03/2015.1
Glade B. Curtis. 2009. Kehamilan diatas usia 30. Jakarta. Arcan

Hapsari \& Sudarmiati. Sexual experience in pregnant woman at pondok aren tangerang health center. 2011;76-85. http://journal.unair.ac.id/article 4847 media37 category3.html. Di akses pada tanggal $21 / 02 / 2015$.

Mulhall. 210. The juornal of sexual medicene. http://onlinelibrary.wiley.com/journal/10.1111/(I

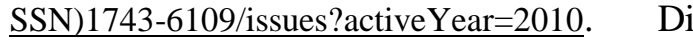
akses pada tanggal 25/03/2015

Murkoff Heidi, Eisenberg, Hathaway 2006. kehamilan apa yang anda hadapi bulan per bulan. Jakarta : Arcan.

Notoatmodjo. 2010. Metodologi penelitian kesehatan. Jakarta; Rineka Cipta.

Pablo Santos PS, dkk. Indice de satisfaccion sexual (ISS): un es tudio sobre su fiabilidady validez. International juonal psychology. 2009; 9, 2, 259-273. https://www.google.co.id/search?q=iss+hudson \&oq=iss\&aqs=chrome.2.69i57j69i60j69i59j013. $3246 \mathrm{j} 0 \mathrm{j} 7$ \& sourceid $=$ chrome\&es $\mathrm{sm}=122 \& \mathrm{ie}=\mathrm{U}$ TF-8. Pada tanggal 25/03/2015.

Polomeno, V. 2000. Sex and Pregnancy: A perinatal educator's guide. The Journal of Perinatal Education. http://www.ncbi.nlm.nih.gov/pmc/articles/P MC1595041/. Pada tanggal 10/10/2015.

Potter, P. A. \& Perry, A G. (2005) Buku Ajar Fundamental Keperawatan: Proses Konsep, dan Praktik, Edisi 4. Jakarta. EGC.

Purwaningsih W, Fatmawati S. 2010. Asuhan keperawatan maternitas.

Ramadani \& Sudarmiati. Perbedaan tingkat kepuasan seksual pada pasangan suami istri dimasa kehamilan. http://jurnal.unimus.ac.id/index.php/JKMat/articl e/view/992. Di akses pada tanggal $03 / 02 / 2015$.

Sandy \& Sari.(2012). Gambaran tentang penegtahuan ibu hamil trimester III tentang hubungan seksual selama hamil. https://www.google.co.id/search?q=iss+hudson 
R. Nety Rustikayanti ${ }^{1^{*}}$, Ira Kartika ${ }^{2}$, Yanti Herawati ${ }^{3}$ Perubahan Psikologis pada Ibu Hamil ...

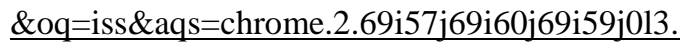
3246j0j7\&sourceid $=$ chrome\&es $s m=122 \& \mathrm{ie}=\mathrm{U}$ TF-

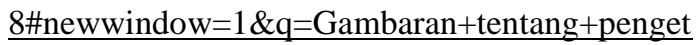
ahuan+ibu+hamil+trimester+III+tentang+hubun gan+seksual+selama+hamil\&spell=1. Di akses pada tanggal 15/03/2015.

Saputra andi.( 2011).Tingkat perceraian di Indonesia meningkat.

http://news.detik.com/read/2011/08/04/124446/1 696402/10/tingkat-perceraian-di-indonesiameningkat. Diakses pada tanggal 04/04/2015

Simkin, Whalley \& Kepper. 2009. Panduan lengkap kehamilan, melahirkan \& bayi. Jakarta : Arcan.

Sugiyono. 2011. Metode penelitian pendidikan. Bandung; Alfabeta

Sylvia D. 2006. Disfungsi seksual pada perempuan.

https://www.google.co.id/search?q=Disfungsi+s eksual+pada+perempuan\&oq=Disfungsi+seksua $1+$ pada+perempuan\&aqs $=$ chrome..69i57j015.825 2j0j4\&sourceid=chrome\&es $s m=122 \&$ ie $=U T F-$ 8. Di akses pada tanggal 11/03/2015. 